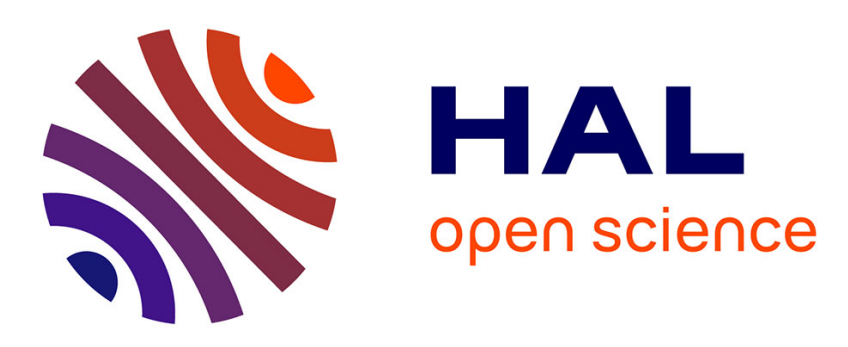

\title{
Rural households decisions towards income diversification: Evidence from a township in northern China
}

\author{
Sylvie Démurger, Martin Fournier, Weiyong Yang
}

\section{To cite this version:}

Sylvie Démurger, Martin Fournier, Weiyong Yang. Rural households decisions towards income diversification: Evidence from a township in northern China. 2009. halshs-00435115

\section{HAL Id: halshs-00435115 \\ https://shs.hal.science/halshs-00435115}

Submitted on 23 Nov 2009

HAL is a multi-disciplinary open access archive for the deposit and dissemination of scientific research documents, whether they are published or not. The documents may come from teaching and research institutions in France or abroad, or from public or private research centers.
L'archive ouverte pluridisciplinaire HAL, est destinée au dépôt et à la diffusion de documents scientifiques de niveau recherche, publiés ou non, émanant des établissements d'enseignement et de recherche français ou étrangers, des laboratoires publics ou privés. 
GATE

Groupe d'Analyse et de Théorie

Économique

Centre National

de la Recherche

UMR 5824 du CNRS

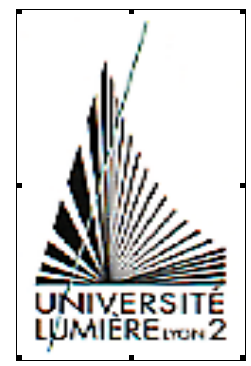

DOCUMENTS DE TRAVAIL - WORKING PAPERS

W.P. 09-23

\section{Rural households decisions towards income diversification: Evidence from a township in northern China}

Sylvie Démurger, Martin Fournier, Weiyong Yang

Novembre 2009

GATE Groupe d'Analyse et de Théorie Économique UMR 5824 du CNRS

93 chemin des Mouilles - 69130 Écully - France

B.P. $167-69131$ Écully Cedex

Tél. +33 (0)4 72866060 - Fax +33 (0)4 72866090

Messagerie électronique gate@gate.cnrs.fr

Serveur Web : www.gate.cnrs.fr 


\title{
Rural households decisions towards income diversification: Evidence from a township in northern China
}

\author{
Sylvie Démurger \\ University of Lyon; CNRS, UMR 5824, GATE, France (demurger@gate.cnrs.fr) \\ Martin Fournier \\ University of Lyon; CNRS, UMR 5824, GATE, France (fournier@gate.cnrs.fr) \\ Weiyong Yang \\ University of International Business \& Economics, Beijing, China \\ (weiyongyang@gmail.com)
}

This version: September 2009

\begin{abstract}
:
Economic reforms in rural China have brought opportunities to diversify both within-farm activities and off-farm activities. Participation in these activities plays an important role in increasing rural households' income. This paper analyzes the factors that drive rural households and individuals in their income-source diversification choices for ten villages in Northern China. At the household level, we distinguish three types of diversification as opposed to grain production only: within farm (nongrain production) activities, local off-farm activities, and migration. At the individual level, we analyze the determinants of participation in three different types of jobs as compared to agricultural work: local off-farm employment, local self-employment and migration. At the household level, we find that land and labor availability stimulates on-farm diversification. Local off-farm activities are mostly driven by household wealth and credit constraints, while migration decisions strongly depend on the household age and composition. At the individual level, we find a clear gender and age bias in access to off-farm activities that are mostly undertaken by male and by young people. More surprisingly, education is found to play a role for accessing local wage employment but not in migration decision. As at the household level, the household assets position is found to strongly affect participation in any off-farm activity.
\end{abstract}

Keywords: income-source diversification, agricultural households, off-farm employment, China.

JEL codes: J2, R2, Q1, O53

\section{Corresponding author:}

Sylvie Démurger

Groupe d'Analyse et de Théorie Economique (GATE) - CNRS UMR 5824

93, chemin des Mouilles - B.P.167

69131 Ecully cedex - FRANCE

Tel: +33(0) 472866105

Fax: +33(0) 472866090

E-mail: demurger@gate.cnrs.fr 


\section{Rural households decisions towards income diversification: Evidence from a township in northern China}

\section{Introduction}

Over the past decades, there has been an outstanding trend of activity diversification in rural areas in developing countries. A rich related literature suggests that rural households adjust their activities either to exploit new opportunities created by market liberalization (Delgado \& Siamwalla, 1997) or to cope with livelihood risks (Barrett et al. 2001a; Carter, 1997). These adjustments are found to have an important impact on income, income distribution and welfare across rural households (Block \& Webb, 2001; Canagarajah et al. 2001; de Janvry \& Sadoulet, 2001; Ellis, 1998, 2000; Hoogeveen, 2001; Reardon et al. 2000).

In China, the launching of economic reforms from the end of the 1970s has led to important changes in productive activities in rural areas. Pre-reform central planning and regional economic self-sufficiency policies had resulted in specialization patterns quite frequently disconnected from local comparative advantages. As a consequence, the rural economy was overwhelmingly dominated by agricultural activities, with grain crops accounting for more than 80 per cent of total sown area. Economic reforms have brought incentives and opportunities for rural households to diversify both within-farm activities and off-farm activities. First, the Household Responsibility System led to the dismantling of the People's Communes and made it progressively possible for rural households to take private decisions regarding their economic activities. At the same time, the emergence of market mechanisms through price reforms and the development of free markets encouraged profitoriented activities. And more recently, China's joining the WTO has accelerated structural adjustments, from land-intensive grain production to more labor-intensive activities, including fruits and vegetables crops, animal husbandry and rural industrialization.

China’s rural economy has been diversifying at various levels. First, the agricultural production itself has been diversified with a constant decline of farming and a steady rise of husbandry, forestry and fishery in terms of output value. Second, the importance of grain in the farming sector has dropped rapidly in favor of cash crops, whose share increased from 20 per cent of total sown area in 1978 to 35 per cent in 2003. Third, non-farm activities have thriven as illustrated by both the prosperity of rural enterprises and the huge flows of rural 
migrants to urban areas. Using macroeconomic data from Chinese provinces between 1985 and 2001, Yang (2009) has shown that this production restructuring from grain crops to cash crops and the labor shift from cropping to non-agricultural activities have both significantly contributed to rural income increase and income stability in China.

The diversification of activities in rural areas is of great concern for rural development not only because of its expected impact on income and poverty reduction, but also because of its importance for the understanding of out-migration movements and rural exodus. Given the size of the rural population in China, gaining a good understanding of how the transition is taking place is essential for the design of adequate rural and urban development policies. A key question is thus whether or not opportunities to develop nonagricultural activities are big enough to foster the expansion of middle-size cities and towns in rural areas, or if one should continue to encourage huge flows of rural population into big cities.

The purpose of this paper is to highlight the main factors that drive rural households as well as individuals in their decision to diversify their economic activities. We use an original household survey conducted in December 2003 in 10 villages of Labagoumen township, a rural township located at the northern border of Beijing municipality. Traditional activity in Labagoumen township used to be grain production. Economic reforms have increased opportunities for households in the township to start new activities both on farm and outside farm. The survey provides detailed information on 293 households and 627 working individuals, including information on diversification behaviors and activity choices. Although the focus is on a small area, we hope that the analysis presented below may give useful insights as to how income-source diversification is working in rural China.

The rapid increase of off-farm opportunities in rural China, illustrated by the development of rural enterprises and a soaring rural-urban migration, has motivated an array of empirical research on the determinants of participation in off-farm activities in China. Most papers tend to focus on a particular choice among the different alternatives, especially on the determinants of migration (e.g. Zhao, 1999; Zhu, 2002), or to consider off-farm activities as a group without separating the different types of jobs (Zhang et al., 2002). Noticeable exceptions are De Brauw et al. (2002) and Shi et al. (2007) that offer detailed analyses of the determinants of individual participation in various sub-categories of off-farm jobs. However, less emphasis has been given to household level choices and especially to the explanation of differences of strategies among households in terms of income-source diversification. Our paper intends to contribute to the literature by analyzing economic 
diversification strategies as a whole. As a consequence, we not only focus on individual labor allocation between farm and off-farm activities, but we also consider household level decisions that include within-farm diversification strategies.

The questions of interest in studying income-source diversification are the following: i) What types of on-farm and off-farm activities do rural households engage in? ii) What determines individual participation in the various off-farm activities? iii) What policy implications can be drawn to reduce rural poverty? To answer these questions, we proceed in two steps. First, we analyze household level decisions to diversify among several alternatives: within farm activities (towards non-grain production), local off-farm activities, and migration, where no diversification is the reference choice. Second, we analyze the determinants of individual participation in three sub-categories of off-farm activities: local off-farm employment, local self-employment and migration, where agricultural work is the reference choice.

The paper is organized as follows. Section 2 highlights diversification patterns observed in Labagoumen township over the recent years. Section 3 discusses the determinants of rural households' decision to diversify their economic activities. Section 4 provides an econometric analysis of the determinants of rural income diversification behaviors at both the household level and the individual level. Section 5 concludes.

\section{Study area: diversification patterns in Labagoumen township}

Our research is based upon a household survey conducted in December 2003 and covering 322 households, with 293 households engaged in productive activities and 627 working individuals. The surveyed area comprises ten villages in Labagoumen township located in the north of Huairou county, Beijing municipality. The township government is situated $160 \mathrm{~km}$ away from Beijing city and $93 \mathrm{~km}$ from Huairou county seat (Map 1). With 302 square kilometers, Labagoumen is the biggest township in Huairou county. It is composed of 15 administrative villages, with a population of almost 7,000 inhabitants among which one third of Manchu minority. Although it belongs to the rich municipality of Beijing, the township is a rather poor area as compared to both neighboring townships and provinces ${ }^{1}$.

The rural economy in this township has been traditionally dominated by farm activities. Surrounded by high and steep mountains, it does not enjoy favorable endowments

\footnotetext{
${ }^{1}$ In terms of per capita GDP, Labagoumen township is the second poorest township in Huairou county, with 5,668 Yuan (approx. 2,715 PPP\$) per capita per year in 1999.
} 
in arable land. At the township level, arable land only accounts for three per cent of total land while forestland represents 83 per cent. The population pressure upon land is also severe, with an average farm size of less than 0.5 hectare per household. Until recently, the agricultural sector alone was employing most of the active population, and the area was relying on subsistence agriculture and the production of corn for seed. Agricultural households surveyed in 2003 allocated on average 51 per cent of their arable land to food crops $^{2}$, the proportion rising up to 82 per cent when corn for seed is included. Land scarcity and land fragmentation strongly constrain crop diversification: with corn being the main crop, it may appear more rational to keep the current production pattern on a network of plots belonging to different households rather than to diversify the production structure on such small plots.

In recent years however, the township has started to move to a wider range of activities, both within and out of the agricultural sector. At the household level, three types of diversification can be identified: on-farm diversification within agriculture, local off-farm activities, and rural-urban migration. A household falls into the category of "on-farm diversification” if it cultivates products of higher value-added than grain (like ginseng, liquorice, or fruit trees), "local off-farm diversification” if it has at least one member involved in local off-farm work and "migration" if it has at least one member with a migration experience over the last 5 years. Our data show that although $34.1 \%$ of the surveyed households had not yet engaged in any economic diversification in 2003, 30\% undertook onfarm diversification, 29.3\% were involved in local off-farm activities and $25.6 \%$ in migration. Since some households may engage into more than one diversification activity, the total of the percentages given here does not sum up to $100 \%$. In the rest of the paper, we make an additional assumption regarding the "degree” of diversification so that every household can fall into one and only one category. We assume that engaging in migration somehow reflects a higher involvement in diversification as compared to all other alternatives and that engaging in local off-farm activities reflects a higher diversification than on-farm diversification only. As a consequence, the categories are nested as follows: "migration" comprises all households for which at least one member has had a migration experience over the last five years, whether or not the household is engaged in on-farm diversification and/or local off-farm activities; "local off-farm activities" includes households for which at least one member is working off-farm in the local area whether or not the household is engaged in on-

\footnotetext{
${ }^{2}$ Food crops include corn, soybean, sorghum, sweet potato, rice, millet, peas and wheat.
} 
farm diversification, but excludes those households also involved in migration; "on-farm diversification" includes households only engaged in on-farm diversification. With this restricted definition, the respective percentages of households engaged in income-source diversification are $16.7 \%$ for on-farm diversification, $23.6 \%$ for local off-farm and $25.6 \%$ for migration (Table 1).

Concerning on-farm diversification, the market development that characterized China over the past three decades has led to the commercialization of agricultural production, which is thus becoming more profit-oriented and increasingly guided by market conditions. Therefore, farmers in the township have started to convert some land from corn crop to higher value-added agricultural products, including American ginseng, liquorice and fruit trees. These productions are better related to the local comparative advantages in terms of climatic and topographic conditions, and they benefit from a direct access to the market through the regular inflow of tourists in the area. Moreover, farmers who turned to these new activities have benefited from various sets of preferential policies and subsidies ${ }^{3}$.

As for non-farm activities, two main occupational choices can be distinguished: individuals can either leave the farm and take a local non-agricultural work, or migrate to towns and cities. As shown by De Brauw et al. (2002), choices have shifted over time towards an increased migration, which had become the most prevalent form of off-farm activity in rural China by 2000. Although migration was not so much widespread in our research area in 2003, villagers, mostly young people, are engaged in migration, with migrants accounting for $15.6 \%$ of the total active population. Owing to proximity to big cities such as Huairou and Beijing and to a relatively well-developed infrastructure network in the region (most villages are served by relatively well-maintained roads), a quarter of rural households had at least a member with a migration experience over the last 5 years, mostly within Beijing municipality (about 23\% of migrants work within their county, 30\% in neighboring counties, and 35\% in Beijing city).

Since there are very few manufacturing enterprises in Labagoumen township, local non-farm activities are mostly related to services. One village (Sunzazhi) benefits from a particular position at the entrance of a Nature Reserve, which recently favored the

\footnotetext{
${ }^{3}$ Preferential policies and subsidies vary across villages. In Xiahebei village, government subsidies of 500 yuan, plus $50 \mathrm{~kg}$ of cereal per $m u$ have been given to households who started American ginseng culture. In Zhongyudian village, besides a subsidy of 400-500 yuan per $m u$, interest-free loans were also offered to households starting American ginseng cultivation. The implementation of the Sloping Land Conversion Program in the township since 2001 also brought subsidies for tree planting. On average, 26\% of agricultural land had been converted by the end of 2003. Most of the land conversion (68\% of converted land) concerns fruit trees, mainly chestnut trees, apricot trees and hawthorn trees (Crataegus laevigata).
} 
development of tourism. The establishment of the Nature Reserve in 1999 has led to the opening of family hotels, restaurants and the development of related tourist activities. Other non-farm activities include working for public services, local government, etc.

Even though farmers are free to choose the crops they grow since the early 1980s, when the Household Responsibility System was introduced, their choice in terms of diversification still largely depends on villages' strategies. As can be seen from Table 1, there are large differences across villages in the speed of activity restructuring. These differences come from differences in natural endowments as well as from differences in the villages' dynamism. Important disparities in resource endowments condition the villages' ability to create income opportunities out of traditional cropping. Some fortunate villages are endowed with specific tourist sights or specific land characteristics, which attract outside investors and provide them with favorable initial conditions. Moreover, activity diversification also strongly depends on policies implemented at the local level to promote economic restructuring. Some dynamic villages did actively promote alternative activities by providing villagers with information as well as incentives, while some conservative villages even forbade the process by imposing grain production to all households. In dynamic villages, the range of measures that has been adopted to encourage activity restructuring includes cash subsidies, longer land-use right, favorable terms, and training.

By providing additional income sources independent of the agricultural cycle, offfarm activities can increase both the level and the stability of household income (Ellis, 2000; Hoogeveen, 2001; Alderman \& Paxson, 1992; Yang, 2009). As shown in Table 2, although farm income still represents more than one third of households' annual income, for those households with income from a specific source, off-farm income is by far the most remunerative. In particular, while remittances account for a rather small share in households' income for the total sample (7.6\%), they represent half of the income for households with migrant members. Tourism can also be a worthwhile alternative to favor rural economic development in the township since the average annual income is as high as 8,000 yuan among households involved in tourism activities. Moreover, Table 3 shows a clear relationship between diversification patterns and per capita households' income. Although the causality can be of a bidirectional nature, it clearly reveals an over-representation of non-diversifying households in the poorest quartiles and an over-representation of households engaged in (local and non-local) off-farm activities in the richest quartiles. In sum, the remunerative nature of off-farm activities calls for a better understanding of the conditions for accessing these activities. 


\section{The determinants of households' diversification behaviors: theoretical linkages}

Various explanations for diversification behaviors can be found in the economic literature to explain both incentives and disincentives for rural households to combine traditional crops with new crops (Norman, 1974), agricultural crops with animal husbandry or forestry activities (Kurosaki, 1995, 1997), and/or agricultural activities with off-farm activities such as migration and tourism (Barrett et al., 2001; Murphy, 1999). On one hand, in a changing economic and institutional environment, agricultural households have incentives to find alternative income sources in order to secure their livelihood. But on the other hand, several factors such as risk aversion and barriers to entry can also hold them back from engaging into new activities.

A rich literature on income diversification in rural areas has identified a wide range of explanatory factors for activity restructuring out of subsistence farming at the household level (Abdulai \& CroleRees, 2001; Smith et al., 2001; Ellis, 1998). The motives are usually divided into two categories: "pull factors" and "push factors" (Barrett et al., 2001b). Pull factors include benefits from complementarities between activities (Norman, 1974), new income opportunities created by market development (Davis and Pearce, 2001), improvement of infrastructure (Jalan \& Ravallion, 1998), and diversification for asset accumulation (Hart, 1994). Push factors include ex ante risk management (Hoogeveen, 2001; Alderman \& Paxson, 1992), ex post risk coping (Carter, 1997), high transaction costs (Omamo, 1998), liquidity constraint and credit market failure (Reardon et al., 1994), and the seasonality of agricultural activity (Sahn, 1989). Household livelihood strategies are jointly determined by these two sets of factors. Market development encourages households to reallocate their productive resources to higher-return activities (Xia \& Simmons, 2004), while poor resource endowments, agricultural seasonality, frequent climatic hazards, and poor access to credit may all push rural households to undertake a wider range of activities in order to secure their livelihood.

Risks play a key role in the activity diversification process. Since they strongly influence rural production, income and welfare, risks are major "push" factors that encourage households to turn to a more diversified portfolio of activities (Carter, 1997; Reardon et al., 1992). Both on-farm and off-farm diversification can thus be seen as efficient mechanisms for households to reduce income risks (Ellis, 1998, 2000; Hoogeveen, 2001). However, in a rapidly changing and volatile environment, uncertainty may also make agricultural households more reluctant to engage in new activities. This is particularly the case for poor 
households who typically have a higher absolute risk aversion (Rosenzweig \& Binswanger, 1993). In a poor area, agricultural households may prefer to stick to traditional crops for which risks are known, even though expected returns associated with alternative activities are higher and a more diversified portfolio of activities would certainly reduce the expected hazard of total income. In sum, risk aversion combined with poverty traps, an ageing population and a massive migration of young people may strongly reduce incentives for poor agricultural households to allocate a higher portion of their land to non-food crops.

Risks are abundant in rural China, and given the lack of credit and insurance markets, the risk incidence is heavy for agricultural households. In the heart of a semi-dry area of northern China, Labagoumen township is exposed to climatic risks, especially droughts. Additional sources of risk in the area come from numerous market imperfections brought by institutional reforms. Given the uneven development process as well as the incompleteness of the reforms, price risks have become a prominent risk for agricultural households. Indeed, in contrast to stable State procurement prices prevailing before the reforms started, farmers now face volatile and unpredictable market prices for agricultural products, especially for "new" products whose market is often very thin and highly fragmented.

Many studies have also shown that the rural poor have less access to lucrative alternative activities than their better-off counterparts because of high barriers to entry associated with these activities (Barrett et al., 2001a, b; Abdulai \& CroleRees, 2001; Woldenhanna \& Oskam, 2001). One of the most important barriers to entry is credit constraint. Indeed, a restricted access to credit and financial savings can impede high initial investments as well as the acquisition of assets that are essential to most non-farm activities (Barrett, 1997) ${ }^{4}$. In Labagoumen township, credit constraint may be an important factor to explain households decisions to engage in diversification. As reported in Table 4, 44\% of the surveyed households declared having faced a credit constraint over the last 5 years. Among those who had borrowed money over the last 5 years, the vast majority borrowed from parents or friends, and only a few borrowed from institutional lenders such as credit cooperatives (4\%), banks (5\%) and local communities (3\%). Among those households who reported the reasons why they did not borrow from financial institutions, 62\% reported excessive collaterals required for official loans as well as restrictive and inflexible lending

\footnotetext{
${ }^{4}$ Even for farming activities, a restricted access to credit may reduce the incentive to invest in new activities. In Labagoumen township, most of the higher profit agricultural alternatives such as American ginseng, liquorice and tree planting require initial investment and long delays. This implies that households have to find the required initial amount plus additional income to live on before they can receive any return from their investment (a few years for ginseng, more for fruit trees, and decades for timber plantation).
} 
conditions as the main reason, followed by refusals from financial institutions (24\%), high interest rates (13\%) and the lack of financial institutions (1\%).

In addition to financial constraints, another important barrier to entry to betterremunerated activities lies in skills and education constraints (Smith et al., 2001). In Labagoumen township, the educational attainment of farmers is low, with only 4.7 years of schooling for an average worker. Unskilled poor have no choice but to stick to activities with low education requirements and this low education level may reinforce inertia in terms of diversification behaviors. The situation may get even worse because of the sharp increase in educational costs that occurred over the past two decades in rural China. Data from our survey indicate that the average annual cost of education per child is about 2,000 yuan for children aged below 16 and jumps to more than 8,000 yuan for university-aged children. Most households cannot afford such educational costs, which leads to early dropout, even before the nine years of compulsory education. In the long run, the high cost of education may strongly limit the rural population's ability to enter into more skilled-labor intensive activities.

\section{Econometric evidence}

\section{Methodology}

The determinants of rural income diversification can be modeled through a simple model of participation choice. Considering alternative activities $j(j=1, \ldots \mathrm{J})$, the choice of the household/individual (i) between $\mathrm{J}$ alternatives is determined by the utility level $U^{i j}$ derived from choosing activity $j$ :

$$
U^{i j}=Z^{i} \gamma^{j}+v^{i j}
$$

where $Z$ measures household/individual characteristics.

The chosen (observed) activity $j^{*}$ is the one that maximizes the utility level:

$$
U^{i j^{*}}=\max _{j}\left\{U^{j}\right\}
$$

We use a multinomial logit model to estimate the probability of choosing a particular activity. Within this framework, it can be shown that the probability to choose activity $j$ can be expressed as follows:

$$
P\left(y^{i}=j / Z^{i}\right)=\frac{\exp \left(Z^{i} \gamma^{j}\right)}{\sum_{k=1}^{J} \exp \left(Z^{i} \gamma^{k}\right)}
$$


To identify the model, $\gamma^{\mathrm{k}}$ is normalized to 0 for activity $j=1$. This yields the following choice probabilities:

$$
P\left(y^{i}=1 / Z^{i}\right)=\frac{1}{1+\sum_{k=2}^{J} \exp \left(Z^{i} \gamma^{k}\right)}
$$

and

$$
P\left(y^{i}=j / Z^{i}\right)=\frac{\exp \left(Z^{i} \gamma^{j}\right)}{1+\sum_{k=2}^{J} \exp \left(Z^{i} \gamma^{k}\right)} \quad \text { for } j=2, \ldots \mathrm{J} .
$$

The multinomial logit model is based on the strong assumption of independence of irrelevant alternatives (IIA). We have tested the IIA hypothesis using the HausmanMcFadden test based on comparing the parameters obtained with the multinomial logit with the parameters obtained by excluding the alternatives one by one. The IIA hypothesis cannot be rejected at conventional levels, which allows us to use a multinomial logit model.

As indicated above, we consider two levels of analysis: i) the household choice of activity portfolio, and ii) the individual choice of participation in off-farm activities. The dependant variables are defined as follows. At the household level, we distinguish three types of activity diversification (as opposed to grain production only, the reference category): onfarm diversification (shift from grain to non-grain crops), local off-farm activities, and migration. At the individual level, we analyze the determinants of participation in three types of off-farm jobs (as opposed to agricultural work, the reference category) ${ }^{5}$ : local off-farm employment, local self-employment and migration.

The set of determinants for these two types of choice include human and social capital variables, household composition variables, household assets variables, and local institutions and village characteristics. For the household level choice, human and social capital variables include the household's average age and education level, communist party membership of the household head, as well as the education level of the household head's father. Household composition refers to household size, the number of elderly, and the number of male adults. Household assets include arable land per adult, a wealth composite indicator, credit constraint, and the constrained access to agricultural equipment. Local institutions and village characteristics are taken into account through village fixed effects. For the individual choice, most variables are similar to the household choice regressions, except individual

\footnotetext{
${ }^{5}$ There is no agricultural wage employment in our sample. This implies that off-farm activities refer to non-farm sectors only.
} 
characteristics that include age, education, communist party membership, gender, and the relationship to the household head. A brief description of explanatory variables' definition and construction is given in Appendix.

As de Janvry and Sadoulet (2001), we assume that individual decisions are not independent across members of a given household. As a consequence, multinomial logit estimations for the determinants of individual participation in off-farm activities are run allowing for intra-household correlations through a cluster effect.

Tables 5 and 6 report the estimation results, respectively for the household decision and the individual decision. The reported coefficients are the exponential values that can be easily interpreted in terms of "relative risk ratios": for each variable $z$, the relative risk ratio tells us how the probability of choosing $j$ relative to the baseline alternative changes if $z$ increases by one unit.

Results for the household economic diversification choice

Table 5 reports the estimation results for the household income-source diversification choice. At the household level, human and social capital variables do not appear to have a strong impact on decisions to diversify. We find that older households have a slightly higher probability (5\% more) to participate in on-farm diversification as compared to no diversification and on the opposite, a slightly lower probability (5\% less) to participate in migration. This suggest that older households are more experienced in farming, which favors on-farm diversification, while they are more reluctant to migrate into cities certainly because of a higher risk aversion with old age. Our empirical study at individual level confirms below that most migrants are young people.

The average education level of household members does not have any significant role on diversification decisions. The only, indirect, impact of education is to be found in the education level of the household head's father, which increases the likelihood (by 10\%) of the household to undertake on-farm diversification activities. The potential "social capital" measured by communist party membership of the household head does not appear to have any significant impact at the household level.

Household composition seems more influential in terms of diversification strategies. First, the household size is found to have a positive and significant impact on the decision to diversify agricultural activities: every additional member in a household increases the probability of undertaking on-farm diversification by a factor of 1.66. Second, a larger male labor force is associated with a much higher probability of both local off-farm diversification 
and migration (the relative risk ratios are respectively 2.84 and 7.40). These results can be explained by increasing returns to scale in household chores for households with a larger size and more labor availability that makes it easier for them to let some members engage in offfarm activities. Dercon and Krishnan (1996) on Ethiopa and Tanzania and Micevska and Rahut (2008) on India find similar results. Third, the presence of old members strongly reduces the likelihood of households to participate in migration (and to a lesser extent to engage in on-farm diversification): a higher dependency ratio of the household reduces the labor availability for migration. In sum, we find a stronger impact of the household composition on migration choice as compared to local off-farm, which is consistent with Shi et al. (2007) finding for southern China.

Among household assets variables, credit constraint is by far the one with the strongest impact on households' decisions to diversify. A constrained access to credit strongly reduces the probability of engaging in any diversification strategy, both on-farm and off-farm, locally or elsewhere. This result is consistent with the empirical literature showing that activity diversification is associated with entry-barriers and that financial resources or access to credit are needed to cover the starting-up investment of new activities (e.g. Barrett et al., 2001a, b; Abdulai \& CroleRees, 2001; Woldenhanna \& Oskam, 2001). As for the decision to diversify agricultural production, more arable land per adult also increases the likelihood of on-farm diversification.

A third measure of household assets includes its wealth, computed as a linear combination of household assets indicators through principal components analysis (Filmer \& Pritchett, 1998). The wealth composite index is meant to measure an ex ante level of wealth that is supposedly less subject to endogeneity problems than a simple measure of household income. A set of six indicators has been selected to reflect the household possession of durable goods: ownership of a bicycle, a motorcycle, a color TV, a VCD-DVD player, a refrigerator and a washing machine. The wealth index is defined using the first principal component weights (with the first principal component accounting for $35 \%$ of the variance of our indicators). As for credit access, Table 5 shows that wealth plays an important role for the decision to undertake local off-farm activities, while it does not appear to be significant for migration decision or on-farm diversification. As a general rule, local off-farm decision is driven by households' asset position rather than by human/social capital or household composition. 
Results for individual participation in off-farm activities

At the individual level, the decision to participate in non-farm activities versus family farming work (reference choice) is analyzed in Table 6. Individual characteristics influence participation decisions. As De Brauw et al. (2002), we find a clear gender bias in participation in off-farm activities. Men have a much higher probability to participate in local wage employment, local self-employment and migration than do women. Likewise, young adults are more engaged in all types of non-farm activities than older individuals. Being the child of the household head also increases the likelihood of out-migration while it reduces participation in local self-employment.

Education has a contrasting role on decisions to participate in off-farm activities. A higher education level increases the probability to engage in a local wage work, while it has no impact on migration decision. Compared to empirical evidence in other developing countries, this result is somehow surprising. As noted by Miceska and Rahut (2008), "empirical evidence overwhelmingly finds positive effects of education on participation in non-farm activities". In our case, the fact that education does not significantly affect participation in migration can be related to the nature of jobs offered to rural migrants in Chinese cities. A well-documented feature of the urban labor market in China is that it is highly segmented between urban residents and rural migrants (Démurger et al., 2009; Knight \& Song, 2005). Jobs taken by rural migrants in urban areas are mostly low-skilled jobs, with no specific requirement in terms of education. Although education has been found to be an increasing determinant of individual participation in migration over the 1990s (e.g. Zhang et al., 2002; De Brauw et al., 2002; Shi et al., 2007), the restricted access to better-paid jobs in urban areas may still hinder the importance of education for migration decision. On the other hand, the level of education in rural China is not zero, which implies that primary school education is largely sufficient to take urban low-skilled jobs with no incentives for individuals to get a higher education level. De Brauw and Giles (2008) have highlighted the trade-off between education and migration opportunity. With already high educational costs for rural households, higher expected wages in urban areas increase the opportunity cost of education in the short run as compared to the long-run expected returns to investment in education.

Household asset positions are found to strongly affect individual participation in offfarm activities while household composition does not have much impact on individual decision. The only exception is the number of elderly that negatively influences the decision to migrate. As at the household level, credit constraint strongly reduces participation in off- 
farm activities. Likewise, household wealth increases the likelihood to engage in local offfarm activities, with a stronger effect for self-employment that requires initial investment. Finally, more arable land per adult significantly reduces the probability to migrate: more land will retain more people in agriculture and thus reduce labor availability for migration.

Last, village dummies confirm disparities across villages in activity diversification. As an example, Sunzhazi village located at the entrance of the Nature Reserve is found to be quite dynamic in off-farm diversification, especially in local self-employment that reflects the vigorous development of family hotels and restaurants. In contrast, the remote Maoshan village is found to be significantly conservative in terms of local wage employment and migration.

\section{Conclusion}

The purpose of this paper was to highlight the main factors driving rural households and individuals in their decision to diversify economic activities. In developing countries, income-source diversification is a key livelihood strategy for rural households (Ellis, 1998) and as such, a good understanding of the determinants of access to off-farm sources of income across households is essential for the design of rural development policies.

In spite of the fact that one third of the households in the studied township have not engaged yet in any form of economic diversification, both non-grain cropping and off-farm activities contribute to an increased average total household income in the area. As in many parts of western China, villages in this mountainous region are characterized by land scarcity and by the absence of any strong comparative advantage in agricultural activities. Among offfarm activities, tourism and migration are by far the most remunerative activities for households in the township. Hence, increasing rural income and reducing rural poverty strongly relies upon the development of off-farm activities, including the development of a local rural industry, tourism as well as migration.

Conditions for success are based on the ability to increase access to off-farm activities for all rural households, particularly for households with little human, land and monetary assets. Our econometric analysis of both households' strategies and individual choices shows that key determinants of success are to be found in a better access to credit as well as in wellfunctioning labor markets in both rural and urban areas. On the credit side, we observed that a constrained access to credit (that affects $40 \%$ of the surveyed households) deeply reduces the likelihood to participate in any off-farm activity at both the household and the individual 
level. Hence, to overcome this important barrier to enter into more remunerative off-farm activities, massive efforts are required to develop rural infrastructure and financial markets. Adequate local credit institutions serving small-scale rural investments are essential to release the constraint that most rural households face.

Regarding education, State intervention through the lowering of education costs is also required. As highlighted by De Brauw \& Rozelle (2008), China is lagging far behind of its Asian neighbors in terms of both investment in rural education and educational attainment. Hence, although the average level of education attainment has increased over time in rural China, it remains quite low (only 6.13 years according to De Brauw \& Rozelle, 2008) in view of the nine-year compulsory education goal. Our results confirm this very low level of education, while better educated people are able to take more remunerative local wageearning jobs. Together with the need for higher investment in rural education, our results also suggest that on the supply side, efforts must be done in urban areas to give better access to skilled jobs to rural migrants. If migrants were to be given an equal access to urban skilled jobs as compared to urban residents, higher expected returns to education would probably pull more educated people out of rural jobs.

\section{References}

Abdulai, A., \& CroleRees, A. (2001). Determinants of Income Diversification amongst Rural Households in Southern Mali. Food Policy, 26, 437-452.

Alderman, H., \& Paxson, C.H. (1992). Do the Poor Insure? A Synthesis of the Literature on Risk and Consumption in Developing Countries. Discussion Paper 164, Research Program in Development Studies Centre of International Studies Woodrow Wilson School, Princeton University, Princeton, NJ.

Barrett, C.B. (1997). Food Marketing Liberalization and Trader Entry: Evidence from Madagascar. World Development, 25(5), 763-777.

Barrett, C., Bezuneh, M. \& Abdillahi, A. (2001a). Income diversification, poverty traps and policy shocks in Cote d'Ivoire and Kenya. Food Policy, 26 (4), 367-384.

Barrett, C., Reardon, T. \& Webb, P. (2001b). Nonfarm income diversification and household livelihood strategies in rural Africa: Concepts, issues, and policy implications. Food Policy, 26(4), 315-331.

Block, S., \& Webb, P. (2001). The dynamics of livelihood diversification in post-famine Ethiopia. Food Policy, 26 (4), 333-350. 
Canagarajah, S., Newman, C., \& Bhattamishra, R. (2001). Non-farm income, gender, and inequality: Evidence from rural Ghana and Uganda. Food Policy, 26(4), 405-420.

Carter, M.R. (1997). Environment, Technology, and the Social Articulation of Risk in West African Agriculture. Economic Development and Cultural Change, 45(3), 557-591.

Davis, J., \& Pearce, D. (2001). The rural nonfarm economy in Central and Eastern Europe. In: The Challenge of Rural Development in the EU Accession Process. Lerman, Z and Csaki, C. (eds.). Washington DC: World Bank.

De Brauw, A., \& Giles, J. (2008). Migrant Opportunity and the Educational Attainment of Youth in Rural China. Policy Research Working Paper 4526, Washington DC, The World Bank.

De Brauw, A., Huang, J., Rozelle, S., Zhang, L., \& Zhang, Y. (2002). The evolution of China's rural labor market during the reforms. Journal of Comparative Economics, 30, 353-529.

De Brauw, A., \& Rozelle, S. (2008). Reconciling the Returns to Education in Off-Farm Wage Employment in Rural China. Review of Development Economics, 12(1), 57-71.

de Janvry, A., \& Sadoulet, E. (2001). Income Strategies Among Rural Households in Mexico: The Role of Off-farm Activities. Word Development, 29(3), 467-480.

Delgado, C.L., \& Siamwalla, A. (1997). Rural Economy and Farm Income Diversification in Developing Countries. MSSD Discussion Paper No. 20.

Démurger, S., Gurgand, M., Li, S., \& Yue, X. (2009). Migrants as second-class workers in urban China? A decomposition analysis. Journal of Comparative Economics, in press, doi:10.1016/j.jce.2009.04.008.

Dercon, S. (1996). Risk, Crop Choice, and Savings: Evidence from Tanzania. Economic Development and Cultural Change, 44, 485-513.

Dercon, S. (1998). Wealth Risk and Activity Choice: Cattle in Western Tanzania. Journal of Development Economics, 55, 1-42.

Ellis, F. (1998). Survey article: Household strategies and rural livelihood diversification in developing countries. Journal of Agricultural Economics, 51(2), 289-301.

Ellis, F. (2000). Rural Livelihoods and Diversity in Developing Countries. Oxford: Oxford University Press.

Filmer, D., \& Pritchett, L. (1998). Estimating Wealth Effects without Expenditure Data -- or Tears: An Application to Educational Enrollments in States of India. World Bank Policy Research Working Paper 1994, Washington D.C. 
Hart, G. (1994). The Dynamics of Diversification in an Asian Rice Region. In B. Koppel et al. (eds.), Development or Deterioration?: Work in Rural Asia, Boulder, CO: Lynne Reinner.

Hoogeveen, J.G.M. (2001). Income Risk, Consumption Security and the Poor. Oxford Development Studies, 30(1), 105-121.

Islam, R. (1987), Rural Industrialisation and Employment in Asia, New Delhi : International Labour Organisation.

Jalan, J., \& Ravallion, M. (1998). Geographic poverty traps?. Institute for Economic Development, Discussion Paper 86. Boston: Institute for Economic Development, Boston University.

Knight, J., \& Song, L. (2005). Towards a Labour Market in China, Oxford University Press. Kurosaki, T. (1995). Risk and Insurance in a Household Economy: Role of Livestock in Mixed Farming. The Developing Economies, XXXIII-4, 464-485.

Kurosaki, T. (1997). Production Risk and Advantages of Mixed Farming in the Pakistan Punjab. The Developing Economies, XXXV-1, 28-47.

Micevska, M., \& Rahut, D.B. (2008). Rural Nonfarm Employment and Incomes in the Himalayas. Economic Development and Cultural Change, 57(1), 163-193.

Murphy, R. (1999). Return Migrant Entrepreneurs and Economic Diversification in Two Countries in South Jiangxi, China. Journal of International Development, 11, 661-672.

Murphy, R. (2002). How Migrant Labor is Changing Rural China, Cambridge: Cambridge University Press.

Norman, D.W. (1974). Rationalising Mixed Cropping under Indigenous Conditions: The Example of Northern Nigeria. The Journal of Development Studies, 11(1), 3-21.

Omamo, S. (1998). Transport Costs and Smallholder Cropping Choices: An Application to Siaya District, Kenya. American Journal of Agricultural Economics, 80(1), 116-123.

Reardon, T., Crawford, E., \& Kelly, V. (1994). Links between nonfarm income and farm investment in African households: Adding the capital market perspective. American Journal of Agricultural Economics, 76(5), 1172-1176.

Reardon, T., Delgado C., \& Matlon, P. (1992). Determinants and Effects of Income Diversification Amongst Farm Households in Burkina Faso. The Journal of Development Studies, 28(2), 264-296.

Reardon, T., Taylor, J., Stamoulis, K., Lanjouw, P., \& Balisacan, A. (2000). Effects of nonfarm employment on rural income inequality in developing countries: An investment perspective. Journal of Agricultural Economics, 51(2). 
Rosenzweig, M., \& Binswanger, H.P. (1993). Wealth, Weather Risk and the Composition and Profitability of Agricultural Investments. Economic Journal, 103, 56-78.

Sahn, D.E. (1989). Seasonal Variability in Third World Agriculture: The Consequences for Food Security. Baltimore, MD: John Hopkins Press.

Shi X., Heerink, N., \& Qu, F. (2007). Choices between different off-farm employment subcategories: An empirical analysis for Jiangxi Province, China. China Economic Review, 18(4), 438-455.

Smith, D. R., Gordon, A., Meadows, K., \& Zwick, K. (2001). Livelihood diversification in Uganda: Patterns and determinants of change across two rural districts. Food Policy, 26(4), 421-435.

Xia, Q., \& Simmons C. (2004). Diversify and Prosper: Peasant Households Participating in Emerging Markets in Northeast Rural China. China Economic Review, 15(4), 375-397.

Woldenhanna, T., \& Oskam, A. (2001). Income Diversification and Entry Barriers: Evidence from the Tigray Region of Northern Ethiopia. Food Policy, 26(4), pp.351-365.

Yang, W. (2009). Economic Structural Changes and Rural Income: Evidence from Chinese Provinces during the Reform Period. China Economic Review, in press, doi:10.1016/j.chieco.2009.05.009.

Zhang, L., Huang J., \& Rozelle, S. (2002). Employment, emerging labor markets, and the role of education in rural China. China Economic Review, 13, 313-328. 
Table 1 - Households' diversification strategies across villages

\begin{tabular}{lcccc}
\hline & No diversification & On-farm diversification & Local off-farm & Migration \\
\hline Total & $\mathbf{3 4 . 1 \%}$ & $\mathbf{1 6 . 7 \%}$ & $\mathbf{2 3 . 6 \%}$ & $\mathbf{2 5 . 6 \%}$ \\
Dadianzi & $39.3 \%$ & $10.7 \%$ & $17.9 \%$ & $32.1 \%$ \\
Dongcha & $39.3 \%$ & $32.1 \%$ & $10.7 \%$ & $17.9 \%$ \\
Huying & $39.3 \%$ & $17.9 \%$ & $17.9 \%$ & $25 \%$ \\
Labagoumen & $34.6 \%$ & $15.4 \%$ & $26.9 \%$ & $23.1 \%$ \\
Maoshan & $55.6 \%$ & $11.1 \%$ & $11.1 \%$ & $22.2 \%$ \\
Miaoying & $10.7 \%$ & $35.7 \%$ & $28.6 \%$ & $25 \%$ \\
Sidaoxue & $46.4 \%$ & $17.9 \%$ & $14.3 \%$ & $21.4 \%$ \\
Sunzhazi & $16.7 \%$ & $2.1 \%$ & $54.2 \%$ & $27.1 \%$ \\
Xiahebei & $26.9 \%$ & $34.6 \%$ & $11.5 \%$ & $26.9 \%$ \\
Zhongyudian & $46.1 \%$ & $0 \%$ & $19.2 \%$ & $34.6 \%$ \\
\hline Sourc: & & & &
\end{tabular}

Source: Household survey conducted by the authors in 2003.

Notes: The three types of economic diversification are defined as follows: i) "migration" comprises all households for which at least one member has had a migration experience over the last five years, whether or not the household is engaged in on-farm diversification and/or local off-farm activities; ii) "local off-farm activities" includes households for which at least one member is working off-farm in the local area whether or not the household is engaged in on-farm diversification, but excludes those households also involved in migration; iii) "on-farm diversification" includes households only engaged in on-farm diversification. 
Table 2 - Diversification and household income by source, 2003

\begin{tabular}{|c|c|c|c|c|}
\hline & Mean & $\begin{array}{c}\text { Share in total } \\
\text { income }\end{array}$ & $\begin{array}{l}\% \text { of households with } \\
\text { income from the } \\
\text { source }\end{array}$ & $\begin{array}{c}\text { Mean among } \\
\text { households with } \\
\text { income from that } \\
\text { source } \\
\end{array}$ \\
\hline Total income in yuan & 6,015 & & & \\
\hline Per capita income & 1,935 & & & \\
\hline Farm income & 1,645 & $36.7 \%$ & $58 \%$ & 2,818 \\
\hline From grain crop & 917 & $25.5 \%$ & $46 \%$ & 2,006 \\
\hline Off-farm income & 3,434 & $44.3 \%$ & $52 \%$ & 6,663 \\
\hline From tourism & 464 & $3.8 \%$ & $6 \%$ & 8,000 \\
\hline Remittances & 718 & $7.6 \%$ & $12 \%$ & 5,847 \\
\hline Other income & 936 & $19 \%$ & $27 \%$ & 3,429 \\
\hline
\end{tabular}

Source: Household survey conducted by the authors in 2003.

Table 3 - Household diversification behavior across income per capita quartile, 2003

\begin{tabular}{lccccc}
\hline & Total & First (poorest) & Second & Third & Fourth (richest) \\
\hline $\begin{array}{l}\text { No diversification } \\
\begin{array}{l}\text { On-farm } \\
\text { diversification }\end{array}\end{array}$ & $\mathbf{3 4 . 1 \%}$ & $47.1 \%$ & $45 \%$ & $25 \%$ & $18.8 \%$ \\
Local off-farm & $\mathbf{1 6 . 7 \%}$ & $33.8 \%$ & $15 \%$ & $6.6 \%$ & $13 \%$ \\
Migration & $\mathbf{2 3 . 6 \%}$ & $2.9 \%$ & $23.7 \%$ & $31.6 \%$ & $34.8 \%$ \\
\hline
\end{tabular}

Source: Household survey conducted by the authors in 2003.

Notes: see Table 1. 
Table 4 - Borrowing behaviors and access to credit, 1999-2003

\begin{tabular}{|c|c|c|c|c|c|c|c|c|c|}
\hline \multirow{2}{*}{ Village } & \multicolumn{2}{|c|}{ Borrowing households } & \multicolumn{6}{|c|}{ Lenders (as a percentage of borrowing households) ${ }^{\text {b }}$} & \multirow{2}{*}{$\begin{array}{c}\text { Credit } \\
\text { constraint } \\
\text { ratio }^{c}\end{array}$} \\
\hline & Households & Share $^{\text {a }}$ & Parents & Friends & Other persons & $\begin{array}{c}\text { Credit } \\
\text { cooperatives }\end{array}$ & Bank & Collectives & \\
\hline Dadianzi & 15 & $48 \%$ & $100 \%$ & $53 \%$ & $0 \%$ & $7 \%$ & $0 \%$ & $0 \%$ & $46 \%$ \\
\hline Dongcha & 22 & $71 \%$ & $91 \%$ & $36 \%$ & $5 \%$ & $9 \%$ & $9 \%$ & $14 \%$ & $39 \%$ \\
\hline Huying & 18 & $60 \%$ & $83 \%$ & $67 \%$ & $28 \%$ & $6 \%$ & $17 \%$ & $0 \%$ & $33 \%$ \\
\hline Labagoumen & 13 & $43 \%$ & $85 \%$ & $85 \%$ & $46 \%$ & $15 \%$ & $0 \%$ & $0 \%$ & $43 \%$ \\
\hline Maoshan & 15 & $50 \%$ & $93 \%$ & $60 \%$ & $7 \%$ & $7 \%$ & $7 \%$ & $0 \%$ & $42 \%$ \\
\hline Miaoying & 16 & $53 \%$ & $94 \%$ & $56 \%$ & $0 \%$ & $6 \%$ & $0 \%$ & $0 \%$ & $45 \%$ \\
\hline Sidaoxue & 13 & $46 \%$ & $85 \%$ & $31 \%$ & $0 \%$ & $8 \%$ & $8 \%$ & $0 \%$ & $29 \%$ \\
\hline Sunzhazi & 32 & $64 \%$ & $69 \%$ & $72 \%$ & $19 \%$ & $0 \%$ & $6 \%$ & $0 \%$ & $45 \%$ \\
\hline Xiahebei & 19 & $63 \%$ & $84 \%$ & $42 \%$ & $11 \%$ & $5 \%$ & $0 \%$ & $0 \%$ & $55 \%$ \\
\hline Zhongyudian & 21 & $70 \%$ & $81 \%$ & $52 \%$ & $19 \%$ & $0 \%$ & $5 \%$ & $5 \%$ & $59 \%$ \\
\hline Total sample & 184 & $58 \%$ & $85 \%$ & $53 \%$ & $11 \%$ & $4 \%$ & $5 \%$ & $3 \%$ & $44 \%$ \\
\hline
\end{tabular}

Source: Household survey conducted by the authors in 2003.

Notes: a. Share of households who have borrowed money during the last 5 years in the total number of surveyed households.

b. The sum of all lenders may exceed $100 \%$, since households can borrow from more than one source.

c. Share of households facing credit constraint in the total number of surveyed households. 
Table 5 - Determinants of economic diversification at the household level

\begin{tabular}{|c|c|c|c|c|c|c|c|}
\hline & \multirow{2}{*}{$\begin{array}{l}\text { Mean } \\
\text { value }\end{array}$} & \multicolumn{2}{|c|}{ On-farm } & \multicolumn{2}{|c|}{ Local off-farm } & \multicolumn{2}{|c|}{ Migration } \\
\hline & & $\begin{array}{l}\text { Relative risk } \\
\text { ratio }\end{array}$ & P-value & $\begin{array}{c}\text { Relative risk } \\
\text { ratio }\end{array}$ & P-value & $\begin{array}{c}\text { Relative risk } \\
\text { ratio }\end{array}$ & P-value \\
\hline \multicolumn{8}{|l|}{ Household characteristics } \\
\hline Average age & 46 & 1.054 & 0.033 & .9635 & 0.236 & .9482 & 0.066 \\
\hline Average education & 4.5 & 1.07 & 0.427 & 1.036 & 0.667 & .997 & 0.981 \\
\hline $\begin{array}{l}\text { Household head party } \\
\text { membership }\end{array}$ & $26 \%$ & 1.208 & 0.673 & 1.293 & 0.595 & .9235 & 0.874 \\
\hline $\begin{array}{l}\text { Household head father's } \\
\text { education }\end{array}$ & 2.2 & 1.106 & 0.115 & 1.053 & 0.445 & 1.035 & 0.594 \\
\hline \multicolumn{8}{|l|}{ Household composition } \\
\hline Household size & 3.1 & 1.658 & 0.089 & .8048 & 0.583 & 1.42 & 0.371 \\
\hline \# Male adults & 1.4 & .970 & 0.949 & 2.845 & 0.045 & 7.400 & 0.000 \\
\hline \# Elderly & 0.5 & .5543 & 0.123 & .6308 & 0.358 & .1874 & 0.017 \\
\hline \multicolumn{8}{|l|}{ Household assets position } \\
\hline Arable land/adult & 2.4 & 1.254 & 0.064 & 1.040 & 0.802 & .858 & 0.327 \\
\hline $\begin{array}{l}\text { Constrained access to } \\
\text { agricultural equipment }\end{array}$ & $16 \%$ & .6363 & 0.456 & .9060 & 0.871 & .788 & 0.660 \\
\hline $\begin{array}{l}\text { Constrained access to } \\
\text { credit }\end{array}$ & $40 \%$ & .502 & 0.107 & .2578 & 0.003 & .3780 & 0.025 \\
\hline Wealth & & .7929 & 0.183 & 1.670 & 0.001 & .9740 & 0.869 \\
\hline \multicolumn{8}{|l|}{ Village characteristics } \\
\hline Sunzhazi village & & 1.006 & 0.996 & 7.404 & 0.001 & 1.702 & 0.433 \\
\hline Dongcha village & & 2.816 & 0.086 & .2193 & 0.119 & .5159 & 0.439 \\
\hline Maoshan village & & .9338 & 0.924 & .3874 & 0.121 & .4809 & 0.273 \\
\hline Miaoying village & & 10.93 & 0.001 & 3.389 & 0.138 & 2.042 & 0.403 \\
\hline Xiahebei village & & 5.962 & 0.003 & 1.282 & 0.780 & 2.732 & 0.145 \\
\hline $\begin{array}{l}\text { Number of observations } \\
\text { in the category }\end{array}$ & 269 & 48 & & 60 & & 70 & \\
\hline Pseudo $\mathrm{R}^{2}$ & 0.28 & & & & & & \\
\hline
\end{tabular}

Source: Household survey conducted by the authors in 2003.

Notes: The reference choice is "no diversification" (91 observations). Robust standard errors.

The relative risk ratio for a one-unit change in a variable is the exponential value of the corresponding coefficient $(\exp (b)$ rather than b). Standard errors and confidence intervals are similarly transformed. 
Table 6 - Determinants of off-farm individual participation

\begin{tabular}{|c|c|c|c|c|c|c|c|}
\hline & \multirow[t]{2}{*}{$\begin{array}{l}\text { Mean } \\
\text { value }\end{array}$} & \multicolumn{2}{|c|}{$\begin{array}{l}\text { Local wage } \\
\text { employment }\end{array}$} & \multicolumn{2}{|c|}{$\begin{array}{l}\text { Local self- } \\
\text { employment }\end{array}$} & \multicolumn{2}{|c|}{ Migration } \\
\hline & & $\begin{array}{l}\text { Relative } \\
\text { risk ratio } \\
\end{array}$ & P-value & $\begin{array}{l}\text { Relative } \\
\text { risk ratio }\end{array}$ & P-value & $\begin{array}{l}\text { Relative } \\
\text { risk ratio }\end{array}$ & P-value \\
\hline \multicolumn{8}{|l|}{ Individual characteristics } \\
\hline Age & 48.1 & .9425 & 0.002 & .9203 & 0.000 & .8848 & 0.000 \\
\hline Education & 5.1 & 1.178 & 0.005 & 1.035 & 0.546 & .9840 & 0.754 \\
\hline Party membership & $17 \%$ & 1.338 & 0.471 & 1.073 & 0.883 & 1.033 & 0.949 \\
\hline Gender $($ male=1) & $55 \%$ & 3.628 & 0.000 & 5.285 & 0.000 & 3.89 & 0.000 \\
\hline Child of the household head & $14 \%$ & .7489 & 0.648 & .1212 & 0.067 & 2.760 & 0.031 \\
\hline \multicolumn{8}{|l|}{ Household composition } \\
\hline \# Children less than 7 & 0.1 & .8062 & 0.673 & .305 & 0.172 & .5738 & 0.305 \\
\hline \# Elderly & 0.5 & .9890 & 0.969 & .8838 & 0.711 & .6313 & 0.120 \\
\hline \multicolumn{8}{|l|}{ Household assets position } \\
\hline Arable land/adult & 2.3 & .9027 & 0.548 & .8279 & 0.155 & .7365 & 0.048 \\
\hline Wealth & & 1.378 & 0.027 & 1.773 & 0.000 & .9897 & 0.937 \\
\hline Constrained access to credit & $41 \%$ & .3420 & 0.011 & .2342 & 0.004 & .4192 & 0.023 \\
\hline \multicolumn{8}{|l|}{ Village characteristics } \\
\hline Sunzhazi & & 2.154 & 0.122 & 17.27 & 0.000 & 2.269 & 0.172 \\
\hline Dongcha & & .1860 & 0.036 & .2716 & 0.298 & .3566 & 0.154 \\
\hline Maoshan & & .0000 & 0.000 & 2.250 & 0.256 & .4241 & 0.059 \\
\hline Miaoying & & 1.475 & 0.490 & 1.598 & 0.594 & 1.940 & 0.234 \\
\hline Xiahebei & & .1491 & 0.052 & 2.392 & 0.279 & .7334 & 0.570 \\
\hline $\begin{array}{l}\text { Number of observations in the } \\
\text { category }\end{array}$ & 577 & 52 & & 46 & & 90 & \\
\hline Pseudo $\mathrm{R}^{2}$ & 0.35 & & & & & & \\
\hline
\end{tabular}

Source: Household survey conducted by the authors in 2003.

Notes: See Table 5. The reference choice is "agricultural work on family farm” (389 observations).

Individual decisions are not assumed to be independent across members of a given household. Standard errors are adjusted for clustering by households (272 households). 
Map 1 - Beijing Municipality and Labagoumen Township

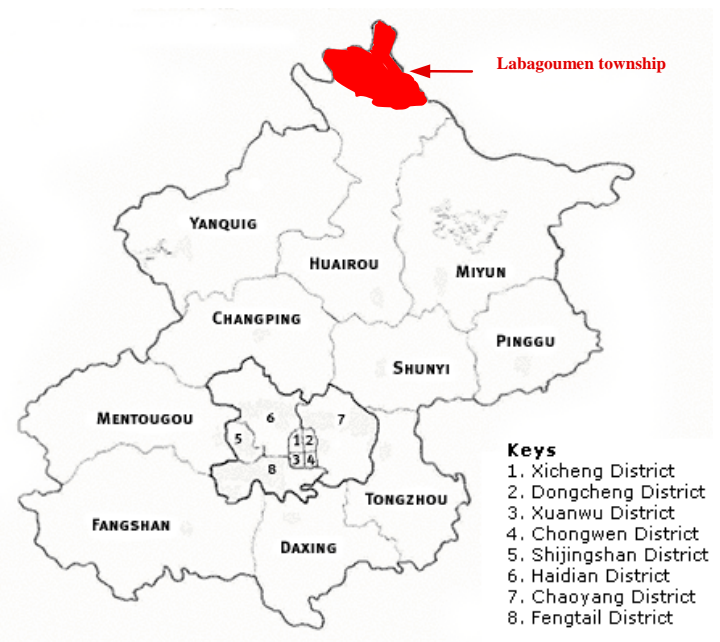




\section{Appendix - Explanatory variables definition}

Household level variables

Average age

Average education

Household head party membership

Household head father's education

Household size

\# Male adults

\# Children less than 7

\# Elderly

Arable land/adult

Constrained access to agricultural equipment

Constrained access to credit

Wealth

Individual level variables

Age

Education

Party membership

Gender

Child of the household head
Average age of all household members

Average number of years of schooling of household members not at school in 2003

Dummy variable: Household head Communist party member $=1$

Number of years of schooling of the father of the household head

Number of permanent members in the household

Number of male adults in the household

Number of children aged less than 7 in household

Number of household members over 65

Arable land are (in $\mathrm{mu}$ ) per adult member of the household

Dummy variable: The household encountered a problem of access to agricultural equipment over the past year $=1$

Dummy variable: Over the past 5 years, the household could not borrow money although it tried to(at least once) $=1$

Wealth composite index computed as a linear combination of household assets indicators through principal components analysis.

Age

Number of years of schooling

Dummy variable: Communist party member $=1$

Dummy variable: male $=1$

Dummy variable: child of the household head=1 